This article was downloaded by: [Australian National University]

On: 16 August 2012, At: 21:56

Publisher: Routledge

Informa Ltd Registered in England and Wales Registered Number: 1072954 Registered office: Mortimer House, 37-41 Mortimer Street, London W1T 3J H, UK

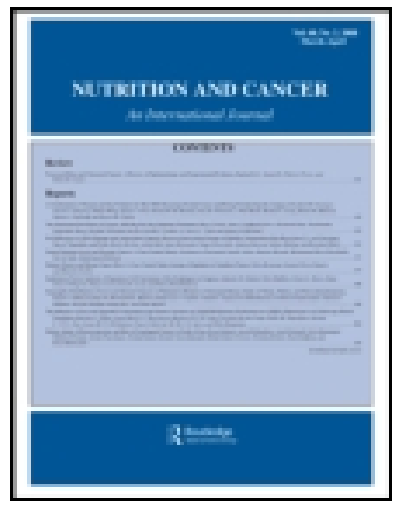

\title{
Nutrition and Cancer
}

Publication details, including instructions for authors and subscription information:

http:// www.tandfonline.com/loi/ hnuc20

\section{Cat's Whiskers Tea (Orthosiphon Stamineus) Extract Inhibits Growth of Colon Tumor in Nude Mice and Angiogenesis in Endothelial Cells via Suppressing VEGFR Phosphorylation}

Mohamed B. Khadeer Ahamed ${ }^{a}$, Abdalrahim F. A. Aisha ${ }^{a}$, Zeyad D. Nassar ${ }^{a}$, J amshed M. Siddiqui $^{\text {b }}$, Z. Ismail ${ }^{\text {b }}$, S.M.S. Omari ${ }^{\text {b }}$, C.R. Parish ${ }^{c} \&$ A. M. S. Abdul Maj id ${ }^{d}$

${ }^{a}$ Department of Pharmacology, School of Pharmaceutical Sciences, Universiti Sains Malaysia, Pulau Penang, Malaysia

${ }^{\mathrm{b}}$ Department of Pharmachemistry, School of Pharmaceutical Sciences, Universiti Sains Malaysia, Pulau Penang, Malaysia

${ }^{c}$ Cancer and Vascular Biology Group, Department of Immunology, J ohn Curtin School of Medical Research, The Australian National University, Canberra, Australia

${ }^{d}$ Department of Pharmachemistry, School of Pharmaceutical Sciences, Universiti Sains Malaysia, Pulau Penang, Malaysia, and Australian Institute for Bioengineering and Nanotechnology, University of Queensland, Brisbane, Australia

Version of record first published: 02 Dec 2011

To cite this article: Mohamed B. Khadeer Ahamed, Abdalrahim F. A. Aisha, Zeyad D. Nassar, J amshed M. Siddiqui, Z. Ismail, S. M.S. Omari, C. R. Parish \& A. M. S. Abdul Majid (2012): Cat's Whiskers Tea (Orthosiphon Stamineus) Extract Inhibits Growth of Colon Tumor in Nude Mice and Angiogenesis in Endothelial Cells via Suppressing VEGFR Phosphorylation, Nutrition and Cancer, 64:1, 89-99

To link to this article: http:// dx.doi.org/ 10.1080/01635581.2012.630160

\section{PLEASE SCROLL DOWN FOR ARTICLE}

Full terms and conditions of use: http://www.tandfonline.com/page/terms-and-conditions

This article may be used for research, teaching, and private study purposes. Any substantial or systematic reproduction, redistribution, reselling, loan, sub-licensing, systematic supply, or distribution in any form to anyone is expressly forbidden.

The publisher does not give any warranty express or implied or make any representation that the contents will be complete or accurate or up to date. The accuracy of any instructions, formulae, and drug doses should be independently verified with primary sources. The publisher shall not be liable for any loss, actions, claims, proceedings, demand, or costs or damages whatsoever or howsoever caused arising directly or indirectly in connection with or arising out of the use of this material. 


\title{
Cat's Whiskers Tea (Orthosiphon Stamineus) Extract Inhibits Growth of Colon Tumor in Nude Mice and Angiogenesis in Endothelial Cells via Suppressing VEGFR Phosphorylation
}

\author{
Mohamed B. Khadeer Ahamed, Abdalrahim F. A. Aisha, and Zeyad D. Nassar \\ Department of Pharmacology, School of Pharmaceutical Sciences, Universiti Sains Malaysia, \\ Pulau Penang, Malaysia
}

\author{
Jamshed M. Siddiqui, Z. Ismail, and S. M. S. Omari \\ Department of Pharmachemistry, School of Pharmaceutical Sciences, Universiti Sains Malaysia, \\ Pulau Penang, Malaysia
}

\author{
C. R. Parish \\ Cancer and Vascular Biology Group, Department of Immunology, John Curtin School of Medical \\ Research, The Australian National University, Canberra, Australia
}

\author{
A. M. S. Abdul Majid \\ Department of Pharmachemistry, School of Pharmaceutical Sciences, Universiti Sains Malaysia, \\ Pulau Penang, Malaysia, and Australian Institute for Bioengineering and Nanotechnology, \\ University of Queensland, Brisbane, Australia
}

\begin{abstract}
Cat's whiskers (Orthosiphon stamineus) is commonly used as Java tea to treat kidney stones including a variety of angiogenesisdependent diseases such as tumorous edema, rheumatism, diabetic blindness, and obesity. In the present study, antitumor potential of standardized $50 \%$ ethanol extract of $O$. stamineus leaves (EOS) was evaluated against colorectal tumor in athymic mice and antiangiogenic efficacy of EOS was investigated in human umbilical vein endothelial cells (HUVEC). EOS at $100 \mathrm{mg} / \mathrm{kg}$ caused $47.62 \pm 6.4 \%$ suppression in tumor growth, while at $200 \mathrm{mg} / \mathrm{kg}$ it caused $83.39 \pm 4.1 \%$ tumor regression. Tumor histology revealed significant reduction in extent of vascularization. Enzyme-linked immunosorbent assay showed EOS $(200 \mathrm{mg} / \mathrm{kg})$ significantly reduced the vascular endothelial growth factor (VEGF) level in vitro $(211 \pm 0.26 \mathrm{pg} / \mathrm{ml}$ cell lysate $)$ as well as in vivo $(90.9 \pm 2$ $\mathrm{pg} / \mathrm{g}$ tissue homogenate) when compared to the control $(378 \pm 5$ and $135.5 \pm 4 \mathrm{pg}$, respectively). However, EOS was found to be noncytotoxic to colon cancer and endothelial cells. In vitro, EOS significantly inhibited the migration and tube formation of human umbilical vein endothelial cells (HUVECs). EOS suppressed VEGF-induced phosphorylation of VEGF receptor-2 in HUVECs.
\end{abstract}

Submitted 13 March 2011; accepted in final form 10 August 2011. Address correspondence to Amin Malik Shah Abdul Majid, Department of Pharmacology, School of Pharmaceutical Sciences, Universiti Sains Malaysia, Minden-11800, Pulau Penang, Malaysia. Phone: +6012 423 0842. Fax: +6 046534 582. E-mail: aminmalikshah@ gmail.com
High performance liquid chromatography (HPLC) analysis of EOS showed high rosmarinic acid contents, whereas phytochemical analysis revealed high protein and phenolic contents. These results demonstrated that the antitumor activity of EOS may be due to its VEGF-targeted antiangiogenicity.

\section{INTRODUCTION}

Colorectal cancer is the second leading cause of death for cancer worldwide, and mortality resulting from this disease, much like many other solid tumors, is not from the primary tumor itself but from metastatic disease that occurs as a result of tumor vascularization, which is a major component of tumor metastasis (1). Highly vascular tumors are more susceptible to develop metastases at a higher rate than less angiogenic tumors (2). A number of angiogenic inhibitors have been developed and successfully been applied in syngenic and heterotransplant tumor models $(3,4)$. Colorectal cancers are highly angiogenic and were the first tumor type to exhibit significant response to angiogenesis inhibitors (5). Many of these inhibitors are directed against the vascular endothelial growth factor (VEGF) or its receptors, which are considered to play a key role in angiogenesis (3).

Orthosiphon stamineus Benth. (Lamiaceae) is a medicinal herb widely distributed in Southeast Asia. Leaves of this plant are commonly used in Southeast Asia and Europe as 
herbal tea, well known as "Java tea." It is used as a traditional medicine for the treatment of a variety of angiogenesisrelated diseases, including rheumatism, tumorous edema, obesity, diabetic blindness, and psoriasis (6,7). Studies have shown that O. stamineus leaves extracts possess strong antioxidant, antiinflammatory, and antibacterial properties with more than 20 phenolic compounds, 2 flavonol glycosides, 9 lipophilic flavones, 9 caffeic acid derivatives, such as rosmarinic acid and 2,3-dicaffeoyltartaric acid $(8,9)$, and nitric oxide inhibitory isopimarane-diterpenes (10). The reports on remedial uses of the herb to alleviate several angiogenesis-dependent diseases like rheumatism, cancer, and retinopathy (6), and the recent evidences that the plant has a significant antiangiogenic activity in rat aortic explants (11), have drawn attention toward hypothesizing that $\mathrm{O}$. stamineus could be useful for treating angiogenesis dependent diseases if its antiangiogenicity is investigated in vitro and scientifically proven using an animal model of angiogenesis-related disease with a standard experimental protocol. Accordingly, the aim of this study is to evaluate the anticancer activity of ethanol extract of $\mathrm{O}$. stamineus leaves (EOS) against colon tumor in athymic mice and to investigate and characterize the antiangiogenic efficacy of EOS in human umbilical vein endothelial cells (HUVECs). This work is an attempt to support its traditional use and further add to previous works on this plant in which suppression of prooxidantsinduced VEGF expression mechanism is thought to play a role.

\section{MATERIALS AND METHODS}

\section{Chemicals, Cell Culture, and Reagents}

Betulinic acid, oleanolic acid, and ursolic acid, bovine serum albumin (fraction V), glucose, quercetin, gallic acid, and FolinCiocalteau reagent were purchased from Sigma (Germany) and sinensetin, 3'-hydroxy-5,6,7,4'-tetramethoxyflavone, and rosmarinic acid were purchased from Indofine Chemical Company (Hillsborough, USA). Other chemicals used were analytical grade.

Human VEGF assay kit was purchased from IBL (Japan). Phosphate buffered saline, trypsin, penicillin/streptomycin (PS), MTT reagent, suramin, and vincristine were purchased from Sigma (Germany). Matrigel was obtained from BD Bioscience (USA). HUVEC (ScienCell, USA) were maintained in endothelial cell medium (ECM) (ScienCell, USA) supplemented with endothelial cell growth supplements, 5\% heat inactivated fetal bovine serum (HIFBS) and 1\% PS. Human colon tumor (HCT 116) and normal colon fibroblast (CCD-18Co) cells were sourced from Rockville (USA), and maintained in RPMI 1640 and DMEM, respectively (Gibco, UK, supplemented with $10 \%$ HIFBS and 1\% PS). NCI Nu/Nu mice (Jackson Laboratory, USA) were maintained in a sterile condition using individually ventilated cages.

\section{Plant Material and Extraction}

Leaves of O. stamineus were obtained from a contract farming facility in Penang, Malaysia. The specimen (Voucher No.: 11009) was deposited at the herbarium of School of Biology, Universiti Sains Malaysia. EOS was prepared by maceration process as previously described (12).

\section{Phytochemical Analysis}

The protein content was determined by Lowry et al. (13), and total polysaccharide content was measured by the phenolsulphuric acid method (14) and glycosaponins content was analyzed by Siddiqui et al. (15). Total phenolics were determined using Folin-Ciocalteau reagent with gallic acid as a standard and the result is expressed as mg of gallic acid equivalent. Total flavonoids were determined using $\mathrm{AlCl}_{3}$ colorimetric method with quercetin as standard and are expressed as $\mu \mathrm{g}$ of quercetin equivalent.

\section{High Performance Liquid Chromatography (HPLC) Analysis}

One hundred $\mathrm{mg}$ of EOS was dissolved in $25 \mathrm{~mL}$ mixture of methanol: water (1:1) and sonicated for $15 \mathrm{~min}$. All samples were filtered through a $0.45 \mu \mathrm{m}$ filter (Whatman). Similarly all reference compounds $(5 \mathrm{mg})$ were dissolved in $5 \mathrm{~mL}$ of methanol and then filtered. Contents of sinensetin, eupatorin, 3'-hydroxy-5, 6, 7, 4'-tetramethoxyflavone, orthosiphol A, rosmarinic acid, betulinic acid, oleanolic acid, and ursolic acid were determined by HPLC fingerprint analysis $(12,16)$.

\section{In Vivo Human Colorectal Tumor Xenograft in Athymic Mouse Model Antitumor Activity of EOS}

HCT 116 cells ( $10^{6}$ in $200 \mu 1$ media) were injected subcutaneously into the right flank of each mouse (4-6 wk old, 20-22 g). Thirty mice randomly divided into 3 groups of 10 mice each. When the average tumor size reached approximately $100 \mathrm{~mm}^{3}$, in about 6 days post-cell inoculation, Group 1 received $0.1 \mathrm{ml}$ distilled water (control), and Groups 2 and 3 received oral treatment with 100 and $200 \mathrm{mg} / \mathrm{kg}$ body weight of EOS, respectively. The regimens were administered by oral gavage once daily for a period of $4 \mathrm{wk}$. Body weights and size of tumors were recorded every 7 days and tumor volume was determined. Apart from the tumor volume, following parameters were also calculated: $\% \Delta \mathrm{T} / \Delta \mathrm{C}$, where, $\Delta \mathrm{T}=\mathrm{T}-\Delta_{0}$ and $\Delta \mathrm{C}=\mathrm{C}-\Delta_{0}\left(\Delta_{0}\right.$ is the average tumor volume at the beginning of the treatment, $\mathrm{T}$ and $\mathrm{C}$ are the tumor volumes at a specified day for treated and control groups, respectively). The optimal $\% \Delta \mathrm{T} / \Delta \mathrm{C}$ value was used as a measure of test sample activity. In general, the $\Delta \mathrm{T} / \Delta \mathrm{C}$ value in percent is used as an indication of antitumor effectiveness, and a value of $\Delta \mathrm{T} / \Delta \mathrm{C} \leq 42 \%$ is considered as significant antitumor activity by the Division of Cancer Treatment, NCI, NIH (17). After 28 days, the mice were sacrificed, and the tumors were removed and weighed. The present work was approved by the USM Animal Ethical Committee [Reference Number USM/PPSG/07(A)/044/(2009)(50)/159]. 


\section{Analysis of VEGF in Colon Tumor Tissue Homogenates}

Tumor tissues $(100 \mathrm{mg})$ were homogenized in $1 \mathrm{~mL}$ lysis buffer (Ray Bio, USA). The homogenates were centrifuged for $10 \mathrm{~min}$ at $4^{\circ} \mathrm{C}(10,000 \mathrm{~g})$, and the supernatants were assessed using VEGF-165 enzyme-linked immunosorbent assay (ELISA). The calibration curve of VEGF standard was used to calculate concentration of VEGF in the samples.

\section{Cytotoxicity Assay}

Cytotoxicity of EOS was evaluated using MTT assay (18) against HCT 116 and CCD-18Co cell lines. The assay plates were read using a microtiter plate reader (Hitachi U-2000, Japan) at $570 \mathrm{~nm}$ absorbance. One percent DMSO was used as a negative control.

\section{In Vitro Antiangiogenic Activity of EOS: HUVEC Proliferation Assay}

HUVECs $\left(2 \times 10^{4}\right.$ cells/well $)$ were allowed to attach in 96-well plates in $100 \mu \mathrm{l}$ growth media containing 1\% VEGF. The cells were exposed to EOS (100 to $3.625 \mu \mathrm{g} / \mathrm{ml}$ ) for 48 h. Proliferation of HUVECs was assessed by MTT assay (18) using vincristine as the reference standard.

\section{Migration Assay}

The assay was performed according to Liang et al. (19) with minor modifications. Briefly, a wound was created using 200$\mu 1$ micropipette tip on a confluent monolayer of HUVECs in a 6-well plate. Two different concentrations of EOS were tested. After $12 \mathrm{~h}$, the wounds were photographed and distances between one side of the scratch and the other were measured using inverted microscope supplied with Leica Quin computerized imaging system. Ten fields for each concentration were captured and minimum 10 readings of distance for each field were measured.

\section{Tube Formation Assay}

The ability of HUVECs to form tube-like structures was investigated on a matrigel matrix. In brief, the matrigel (150 $\mu \mathrm{l} /$ well) was added to 48 -well plate and allowed to polymerize for $45 \mathrm{~min}$ at $37^{\circ} \mathrm{C}$ and $5 \% \mathrm{CO}_{2}$. HUVECs were harvested and seeded onto the matrigel-coated plates. The cells were treated with various concentrations of EOS and incubated at $37^{\circ} \mathrm{C}$ for $24 \mathrm{~h} \mathrm{(20).} \mathrm{Suramin} \mathrm{was} \mathrm{used} \mathrm{as} \mathrm{a} \mathrm{positive} \mathrm{control} \mathrm{at}$ $10 \mu \mathrm{g} / \mathrm{ml}$ in the growth medium. The cells were imaged under an inverted florescence microscope at low magnification and the network length was quantified.

\section{Western Blot Analysis}

HUVECs were cultured in serum-free ECM for $24 \mathrm{~h}$ and then incubated with various concentrations of EOS $(12.5,25$, and 50 $\mu \mathrm{g} / \mathrm{ml}$ ) for $30 \mathrm{~min}$ before VEGF (100 $\mathrm{ng} / \mathrm{ml}$ ) stimulation for 5 $\mathrm{min}$. Total cells extracts were prepared in ice-cold cell extraction buffer (Biousource, Camarillo, CA). Proteins were separated by electrophoresis on SDS gels, transferred onto polyvinylidene difluoride membranes, and incubated with the primary antibody,
antiphospho-VEGFR2. Binding of the primary antibody was detected with a horseradish peroxidase-conjugated secondary antibody and chemiluminescent substrate (Pierce).

\section{Statistical Analysis}

The results were expressed as the mean \pm standard error (SEM), and the statistical significance was evaluated by using the Student's $t$-test. $P$ values $<0.05$ implied significance.

\section{RESULTS}

\section{HPLC Analysis of EOS}

HPLC chromatograms of EOS (absorbance at $330 \mathrm{~nm}$ ) along with the mixed standards are shown in Fig. 1A and 1B. Results from this study are consistent with previous reports, suggesting that rosmarinic acid is one of the major chemical constituents of O. stamineus extracts along with other flavonoids (12). The analytical plots of standards, betulinic acid, oleanolic acid, and ursolic acid along with the sample are shown in Fig. 1C and 1D. Chemical structures of 8 biomarkers used in the study are given in Fig. 1E. Good linearity, retention time, and method validation of 5-point calibration curves were obtained for all replicates (Table 1). The quantitative result of bioactive markers (\% dry weight) is illustrated in Fig. 1F.

\section{Phytochemical Analysis}

The result of quantitative analysis of total proteins, polysaccharides, flavonoids, phenolics, and glycosaponins present in EOS is depicted in Fig. 1G.

\section{Effect of EOS on Colorectal Tumor Growth}

To evaluate the antitumor effect of EOS, HCT 116 cells were injected into nude mice. EOS exhibited dose-dependent suppression in HCT 116 tumor growth relative to vehicle-treated control (Fig. 2A-2C). Morphology of excised tumors (Fig. 2D-2F) showed significant reduction in density of blood vessels in the tumors from treated animals compared to the tumors from control group. Fig. $2 \mathrm{G}$ shows the tumor growth profile in the respective test groups. A significant $\Delta \mathrm{T} / \Delta \mathrm{C}(13.6 \%, P<0.01)$ antitumor activity of EOS $(100 \mathrm{mg} / \mathrm{kg})$ on 28 th post-cell inoculation day (Table 2). At a dose of $200 \mathrm{mg}$ EOS/ $\mathrm{kg}$ on 28th post-cell inoculation day, the result was far more obvious showing potent activity of EOS $(1.45 \%, P<0.001)$. Fig. $2 \mathrm{H}$ shows the average tumor weight from different test groups.

\section{Histopathological Examination}

In histological study, the antiangiogenic effect of EOS was even more pronounced. Fig. 3A and 3B show the typical vehicletreated tumor in which there is no or minimal necrosis and the tumor cells showing compact sheets of polygonal cells with abundant supply of blood vessels (Fig. 3B). In the animals treated with EOS, many tumors showed histological evidence of EOS's antitumor effect. The tumors from these animals showed significant loss of compactness of the cells in the tumor with moderate to severe necrosis, with areas of decreased cell density, many 
TABLE 1

The linearity, correlation coefficient $\left(R^{2}\right)$, limit of detection (LOD), and limit of quantification (LOQ) of the compounds studied

\begin{tabular}{|c|c|c|c|c|c|}
\hline $\begin{array}{l}\text { Standards and } \\
\text { [retention } \\
\text { time (min)] }\end{array}$ & $\begin{array}{l}\text { Linear } \\
\text { range } \\
(\mu \mathrm{g} / \mathrm{mL})\end{array}$ & $\begin{array}{c}\text { Regression } \\
\text { equation }\end{array}$ & $r^{2}$ & $\begin{array}{c}\text { LOD } \\
(\mathrm{ng} / \mathrm{mL})\end{array}$ & $\begin{array}{c}\text { LOQ } \\
(\mathrm{ng} / \mathrm{mL})\end{array}$ \\
\hline Orthosiphol A (7.0) & $0.01-500$ & $y=23.076 x-12.36$ & 0.9999 & 2.0 & 20 \\
\hline TMF (11.2) & $0.01-500$ & $y=49.878 x-11.69$ & 0.9999 & 2.0 & 20 \\
\hline Betulinic acid (11.7) & $0.01-500$ & $y=39.039 x+13.88$ & 0.9993 & 10 & 100 \\
\hline Oleanolic acid (13.6) & $0.01-500$ & $y=54.44 x-24.93$ & 0.9991 & 10 & 100 \\
\hline Ursolic acid (13.9) & $0.01-500$ & $y=49.15 x+7.07$ & 0.9992 & 10 & 100 \\
\hline
\end{tabular}

Note. y indicates peak area; $\mathrm{x}$, concentration $(\mathrm{mg} / \mathrm{mL})$.

small islands of tumor cells, and calcification (an indicator of past necrosis) (Fig. 3C and 3D). The most remarkable change observed in tumor histology was the treatment with $200 \mathrm{mg} / \mathrm{kg}$ of EOS induced reduction in tumor vascular density. In these animals, histology of the tumor was highly disorganized with severe necrosis (Fig. 3E and 3F). In many of these, much of the tumor mass that remained, and was measured, was actually necrotic debris and calcification, and in several cases only a few islands of tumor cells remained.

\section{Inhibition of HUVEC Proliferation and Tube Formation}

In order to confirm the possible mechanism by which EOS inhibits the growth of tumors, an investigation on a series of in vitro angiogenesis models was conducted. We first determined whether EOS inhibited endothelial cell proliferation. Results showed that EOS caused inhibition of HUVEC proliferation at higher concentrations with $\mathrm{IC}_{50} 48.23 \mu \mathrm{g} / \mathrm{ml}$ (Fig. 4A), whereas the standard reference vincristine exhibited potent cytotoxicity with $\mathrm{IC}_{50} 0.13 \mu \mathrm{g} / \mathrm{ml}$. To characterize the antiangiogenic activity of EOS, endothelial cell tube formation assay, a well-established in vitro angiogenesis assay, was conducted. HUVECs cultured on matrigel formed tubelike networks (Fig. 4B) within $8 \mathrm{~h}$, which might, in part, reflect the process of angiogenesis. At a concentration of $25 \mu \mathrm{g} / \mathrm{ml}, 98.26 \%$ inhibition was observed (Fig. 4C), in which EOS absolutely abrogated endothelial tube

TABLE 2

$\% \Delta \mathrm{T} / \Delta \mathrm{C}$ of HCT 116 tumor growth in immunocompromised mice

$\% \Delta \mathrm{T} / \Delta \mathrm{C}$ value with respect to the post-cell inoculation period

\begin{tabular}{lccc}
\cline { 2 - 4 } Dose of EOS $(\mathrm{mg} / \mathrm{kg})$ & $1 \mathrm{st} w \mathrm{k}$ & $2 \mathrm{nd} \mathrm{wk}$ & $3 \mathrm{rd} \mathrm{wk}$ \\
\hline 100 & $19.9^{*}$ & $16.46^{*}$ & $13.6^{* *}$ \\
200 & $<6.41^{* *}$ & $<2.83^{* *}$ & $<1.45^{* *}$ \\
\hline
\end{tabular}

$P<0.05$. ${ }^{* *} P<0.01$. formation, reducing the tubelike structure both in width and in length. Noteworthily, 56.22\% inhibition in tube formation was observed at $12.5 \mu \mathrm{g} \mathrm{EOS} / \mathrm{ml}$ concentration (Fig. 4D), which is much lower than the $\mathrm{IC}_{50}$ value of EOS on HUVEC proliferation. It can be seen clearly that the HUVECs rounded up and rendered network structures incomplete and broken in the presence of EOS. The activity of EOS was more pronounced than the standard drug, suramin, which showed $49.76 \%$ inhibition at a concentration of $10 \mu \mathrm{g} / \mathrm{ml}$ (Fig. 4E).

\section{Inhibitory Effect of EOS on HUVECs Migration}

HUVEC migration assay represents an important step in the formation of new blood vessels and is a straightforward and economical method to study the cell migration phenomenon (19). A scratch wound was created on the monolayer of cells (Fig. 4F), and the effect of EOS on closure of the wound was studied. EOS $(25 \mu \mathrm{g} / \mathrm{ml})$ inhibited HUVECs migration $(P<$ $0.001)$ by $97.33 \%$ after $12 \mathrm{~h}$. Even at a lower concentration of EOS $(12.5 \mu \mathrm{g} / \mathrm{ml})$, a significant $(P<0.05)$ inhibitory effect was observed, with $76.8 \%$ inhibition after $12 \mathrm{~h}$.

\section{Effect of EOS on VEGF-Induced Tyrosine Phosphorylation of VEGFR-2}

Serum-starved HUVECs were treated with various concentrations of EOS for $30 \mathrm{~min}$, followed by VEGF stimulation. Phosphorylation state of VEGFR-2 was assessed by Western blot with anti-phospho-VEGFR2 antibody. Fig. 5A depicts the inhibitory effect of EOS on VEGF-induced tyrosine phosphorylation of VEGFR2 in a dose-dependent manner.

\section{In Vitro Effect of EOS on VEGF level in HCT 116 Cell Lysate}

The level of VEGF in treated and untreated HCT 116 cells was determined by human VEGF 165 ELISA kit. Result showed that the treatment caused a significant decrease in VEGF content in cell lysates when compared to the control $(378 \pm 5 \mathrm{pg} / \mathrm{ml})$. The extract showed dose-dependent reduction of VEGF levels (Fig. 5B). At $25 \mu \mathrm{g} / \mathrm{ml}$, the VEGF level was $310 \pm 0.82 \mathrm{pg}$, 

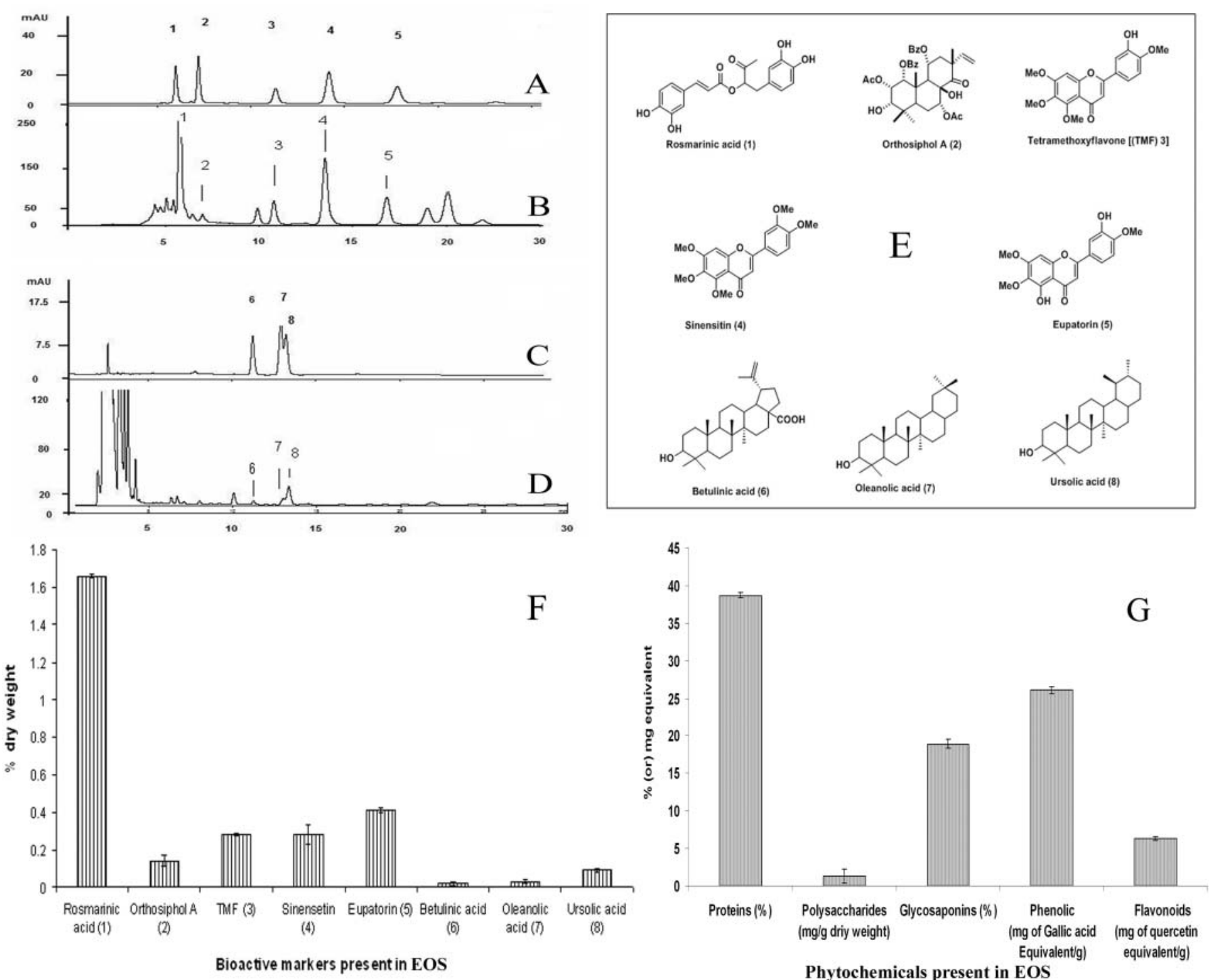

FIG. 1. A, C: High performance liquid chromatography (HPLC) chromatograms of standard markers, rosmarinic acid (1); orthosiphol A (2); 3'-hydroxy-5,6,7,4'tetramethoxyflavone (3); sinensetin (4); eupatorin (5); betulinic acid (6); oleanolic acid (7); and ursolic acid (8). B, D: HPLC chromatograms of ethanol extract of O. stamineus leaves (EOS) showing different proportions of respective markers. E: Chemical structures of marker compounds in EOS. F: Illustration depicts the contents of bioactive markers (\% dry weight) present in EOS. G: Graphical representation of the levels of total proteins, polysaccharides, glycosaponins, phenolic and flavonoid content in EOS. All values are expressed as mean $\pm \operatorname{SEM}(n=6)$.

whereas at $50 \mu \mathrm{g} / \mathrm{ml}$ concentration, VEGF level was decreased drastically to $211 \pm 0.26 \mathrm{pg} / \mathrm{ml}$.

\section{In Vivo Effect of EOS on VEGF Level in Colon Tumor Tissue Homogenates}

Having examined the effect of EOS on tumor vasculature, the level of VEGF in tumor tissues harvested from the treated and control animals was determined. Results showed that the treatment caused a significant decrease in VEGF content in homogenates when compared to the control $(135.5 \pm 4 \mathrm{pg} / 100$ $\mathrm{g}$ of tissue homogenate). EOS showed dose-dependent reduction of VEGF levels (Fig. 5C). At $100 \mathrm{mg} / \mathrm{kg}$ dose, the VEGF level was $112.9 \pm 2 \mathrm{pg} / 100 \mathrm{~g}$ of tissue homogenate, whereas at $200 \mathrm{mg} / \mathrm{kg}$ VEGF level was $90.9 \pm 3 \mathrm{pg} / 100 \mathrm{~g}$ of tissue homogenate.

\section{Effect of EOS on Proliferation of Non-Endothelial Cells}

In order to evaluate the potential cytotoxic activity of EOS, MTT cell proliferation assay was conducted. HCT 116 and CCD-18Co were exposed to different concentrations of EOS. The results showed no significant cytotoxicity as compared to DMSO alone. The $\mathrm{IC}_{50}$ value of EOS against both cell lines was found to be $>100 \mu \mathrm{g} / \mathrm{ml}$ (data not shown). 

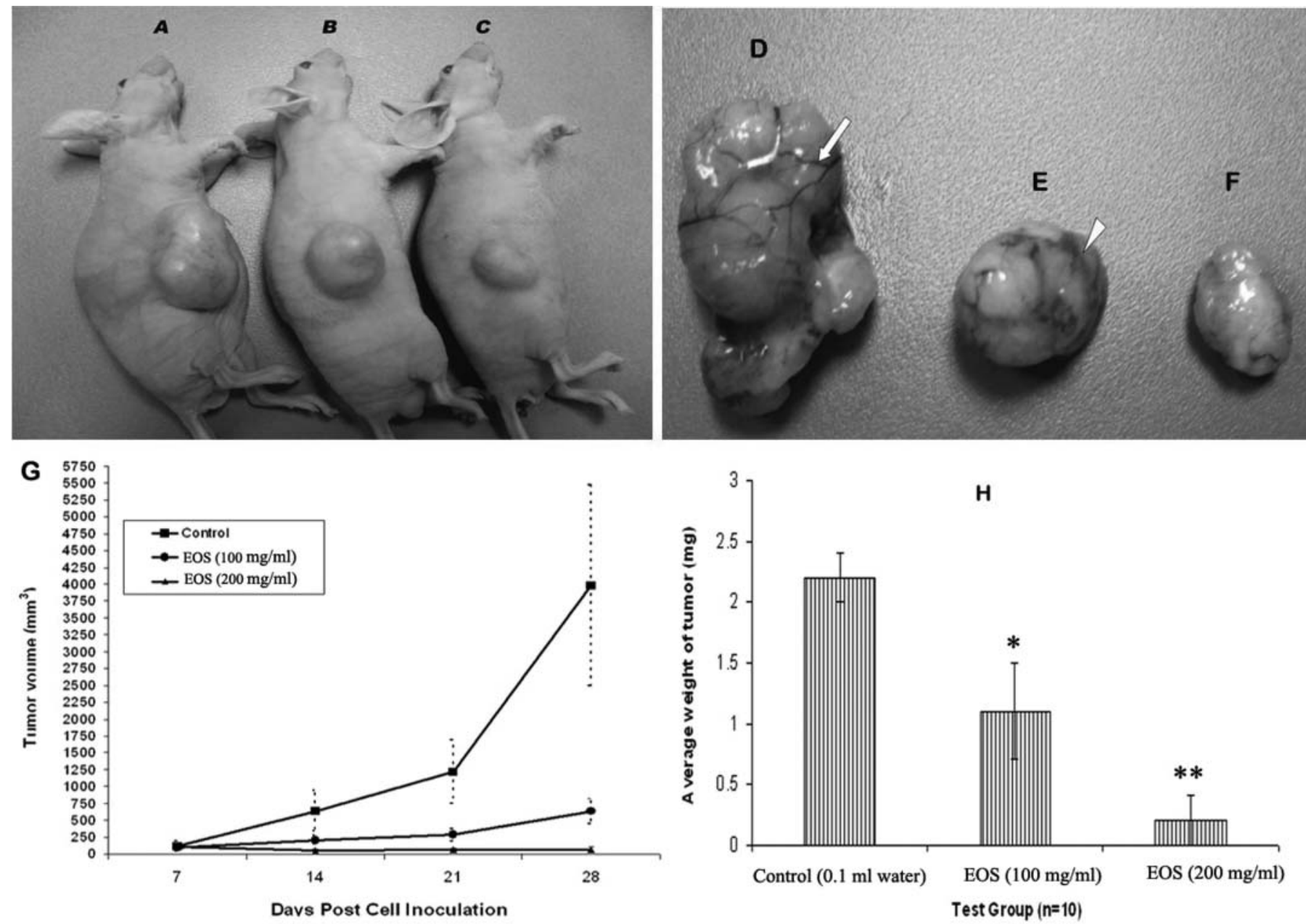

FIG. 2. In vivo antitumor activity in which immunocompromised mice bearing HCT 116 tumors at 28th post-inoculation day. A: Animal without treatment; animal treated with $100 \mathrm{mg} / \mathrm{kg}$ (B) and $200 \mathrm{mg} / \mathrm{kg}$ (C) of ethanol extract of O. stamineus leaves (EOS). D: Tumor harvested from control animal (arrow indicates prompt and well-developed blood vessels in control). E: Tumor harvested from animal treated with $100 \mathrm{mg} / \mathrm{kg}$ EOS (arrowhead points toward the reduction in tumor vasculature caused by EOS). F: Tumor harvested from animal treated with $200 \mathrm{mg} / \mathrm{kg}$ EOS. Here the density of vascularization is nil or negligible. G: Illustrates the comparative effect of 2 different doses of EOS with control group on HCT 116 tumorigenesis in nude mice. H: Effect of EOS on the average tumor weight. All values are expressed as mean \pm S.E.M $(n=10) .{ }^{*} P<0.05,{ }^{* *} P<0.01$.

\section{DISCUSSION}

Dietary antioxidants with antiangiogenic activity have been extensively studied as the core constituents responsible for cancer prevention. Among those that have been identified include vitamin $\mathrm{C}$, vitamin $\mathrm{D}$, vitamin $\mathrm{E}$, vitamin $\mathrm{A}$, betulinic acid, and 3-hydroxyflavone, 3',4'-dihydroxyflavone, $2^{\prime}, 3^{\prime}$-dihydroxyflavone (21). In the present work, the antiangiogenesis efficacy of EOS was shown to be mediated via blocking the VEGF signaling pathway. The oxidants participate actively in the VEGF signaling pathway, which is not just limited to induction of VEGF signal. When VEGF binds to its specific receptors, especiallyVEGFR-2, oxidants are required for the signaling cascade that leads to the angiogenic response of $\operatorname{VEGF}(22,23)$. Reactive oxygen species are responsible to drive the mitogenic cascade initiated by the tyrosine kinase receptor of VEGF (24). EOS effectively inhibited the in vitro and in vivo release of the key angiogenic factor VEGF. On the one hand, EOS strongly inhibited the level of VEGF mitogen in tumor cells; on the other hand, it suppressed the phosphorylation of VEGFR-2 in HUVECs. These effects of EOS could be ascribed mainly to its antioxidant-rich polyphenolic contents, the caffeic acid derivatives, polymethoxylated flavonoids and terpenes, particularly rosmarinic acid, eupatorin, sinensetin, 3'hydroxy-5,6,7,4'-tetramethoxyflavone, and betulinic acid (25). Flavonoids and their metabolic precursors, phenolics, possess very promising antiangiogenic properties (26). However, other non-flavonoid polyphenols, such as rosmarinic acid and betulinic acid also significantly contribute to the antiangiogenic effect of polyphenols-rich plants $(27,28)$. The blockade of the angiogenic process through the inhibition of VEGF signaling has been shown to result in significant tumor growth delay in a wide range of preclinical models and the clinical benefit of this 

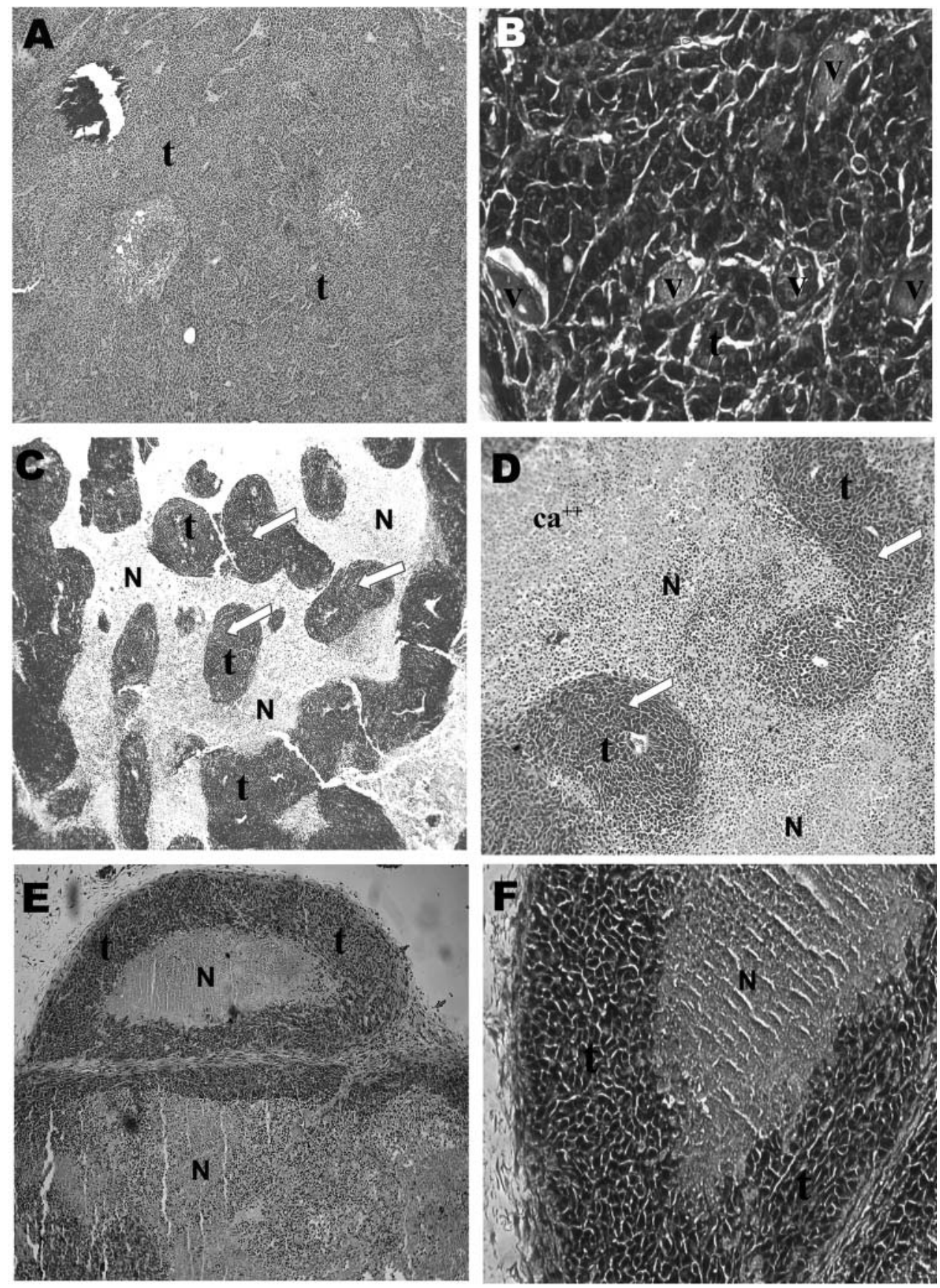

FIG. 3. Necrotic changes in tumor histology and evidence of antiangiogenesis by treatment of ethanol extract of O. stamineus leaves (EOS). At the termination of the study, hematoxylin and eosin (H\&E)-stained tumor sections were examined histologically. A: An H\&E-stained tumor section of a representative animal in the vehicle control group is shown, original magnification of $\times 10$. This tumor is composed of viable tumor cells (designated by " $t$ ") and virtually no necrosis. B: Magnified ( $\times 100)$ tumor section of vehicle control shows well organized tumor with the densely packed viable tumor cells (t) and large number of blood vessels (v). C, D: Significant changes in tumor histology were noted in immunocompromised animals treated with EOS (100 mg/kg), such as loss of compact arrangement of tumor cells, islands (indicated by arrows) of live tumor cells ( $\mathrm{t}$ ) surrounded by necrosis (indicated by "N"), calcification $\left(\mathrm{Ca}^{++}\right)$evidence of previous necrosis, and decreased density of remaining tumor cells (magnification: Fig. 3C 10× and Fig. D 40×). E, F: A representative tumor from EOS (200 mg/kg)-treated group is shown, original magnification of $\times 10$ (Fig. 3E). Central necrosis is markedly observed in this group of tumors. In these animals, tumor architecture was highly disorganized and with moderate to severe necrosis $(\mathrm{N})$. In approximately half of these animals, only a small rim of viable tumor cells ( $t$ ) remained at the periphery and the majority of the mass was actually necrotic debris, as represented by the necrotic tumor from the treatment group shown here, original magnification of $\times 100$ (Fig. 3F). 

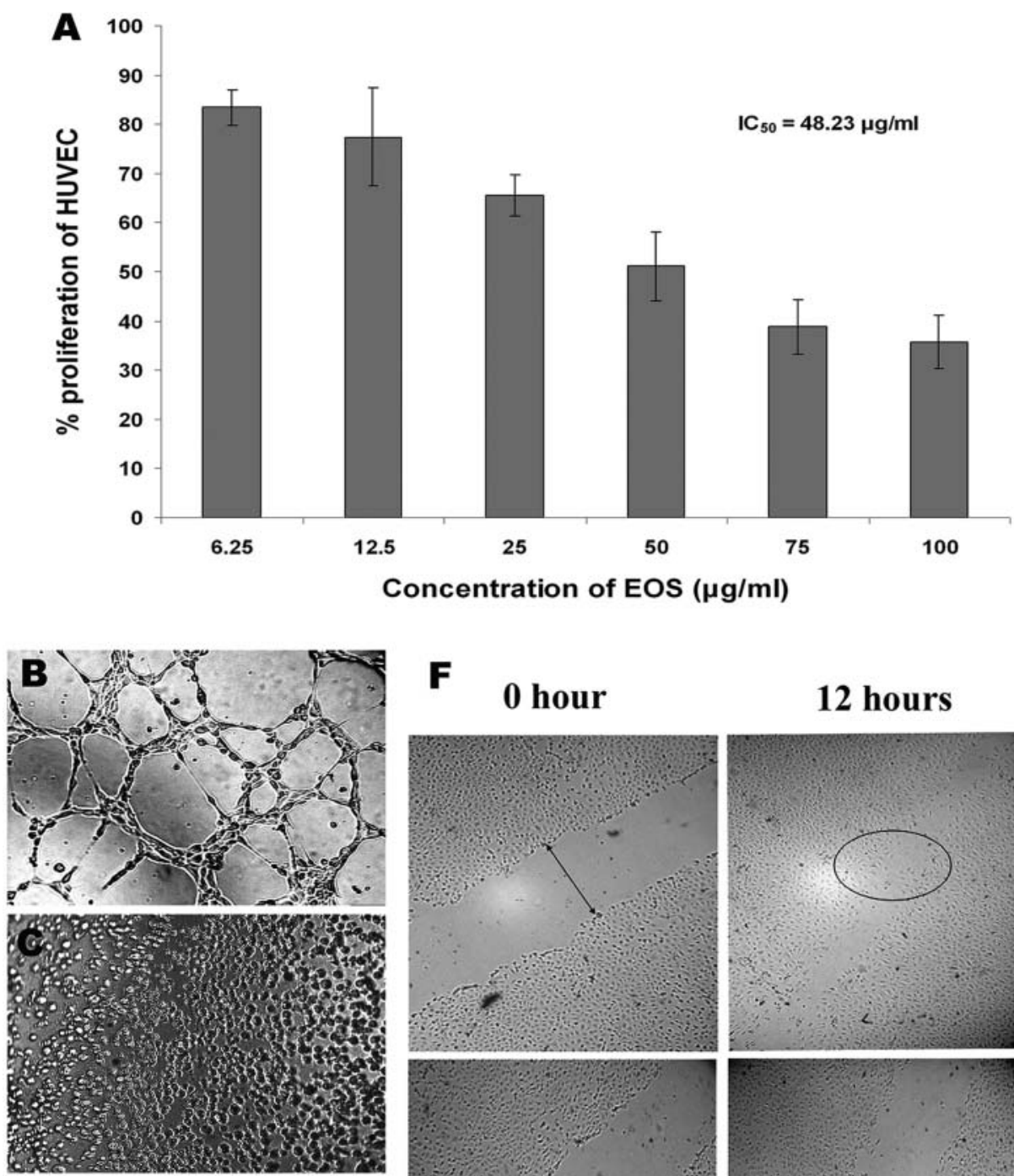
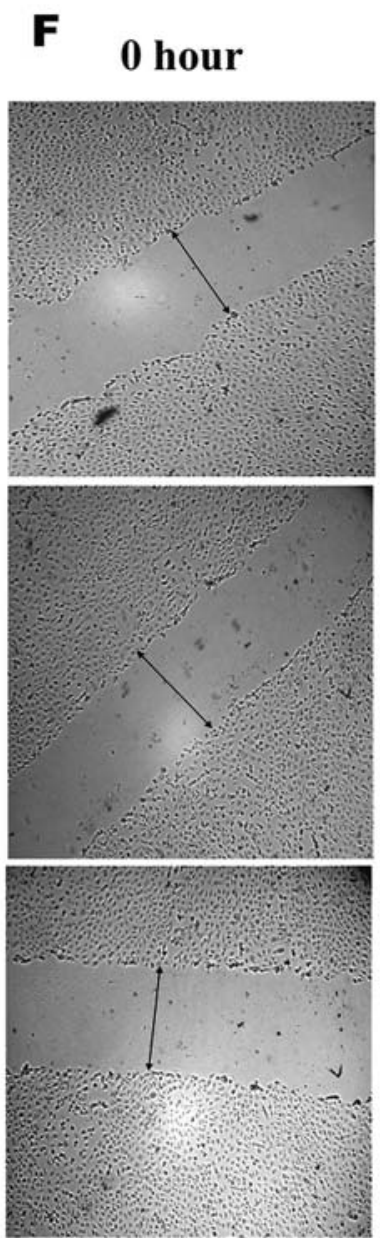

12 hours

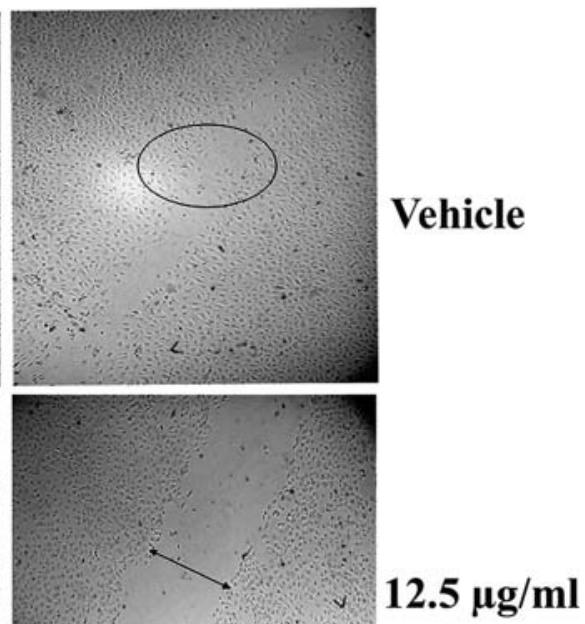

$12.5 \mu \mathrm{g} / \mathrm{ml}$

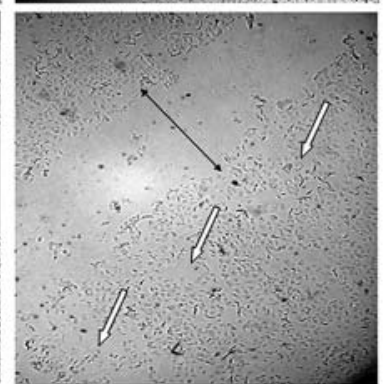

\section{$25 \mu \mathrm{g} / \mathrm{ml}$}

FIG. 4. Effect of ethanol extract of O. stamineus leaves (EOS) on proliferation, tube formation and migration of human umbilical vein endothelial cells (HUVECs). A: Effect of EOS on HUVEC proliferation. EOS inhibited the proliferation in dose-dependent manner with $\mathrm{IC}_{50} 48.23 \mu \mathrm{g} / \mathrm{mL}$. $(n=6$, values are in mean \pm SEM). In tube formation assay, HUVECs $\left(2 \times 10^{4}\right.$ cells/well $)$ were plated on Matrigel precoated 96 -well plates and treated with different concentrations of EOS for $24 \mathrm{~h}$. B: Control; C: EOS (25 $\mu \mathrm{g} / \mathrm{mL})$; D: EOS $(12.5 \mu \mathrm{g} / \mathrm{mL})$; E: Suramin $(10 \mu \mathrm{g} / \mathrm{mL})$. F: Because of the successful migration of endothelial cells in untreated group, the wound is almost closed after $18 \mathrm{~h}$; whereas in EOS-treated group, the wound remained open even after $18 \mathrm{~h}$ incubation. EOS $(12.5 \mu \mathrm{g} / \mathrm{mL})$ caused significant inhibition of endothelial cell migration. At a concentration of $25 \mu \mathrm{g} / \mathrm{mL}$, EOS caused dislodgement of monolayer of endothelial cells (indicated by the arrows) with almost complete inhibition of migration. 
$\mathbf{A}$

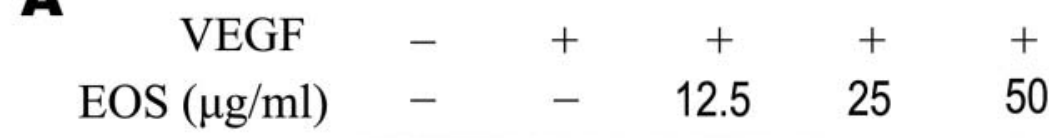

Phospho-VEGFR
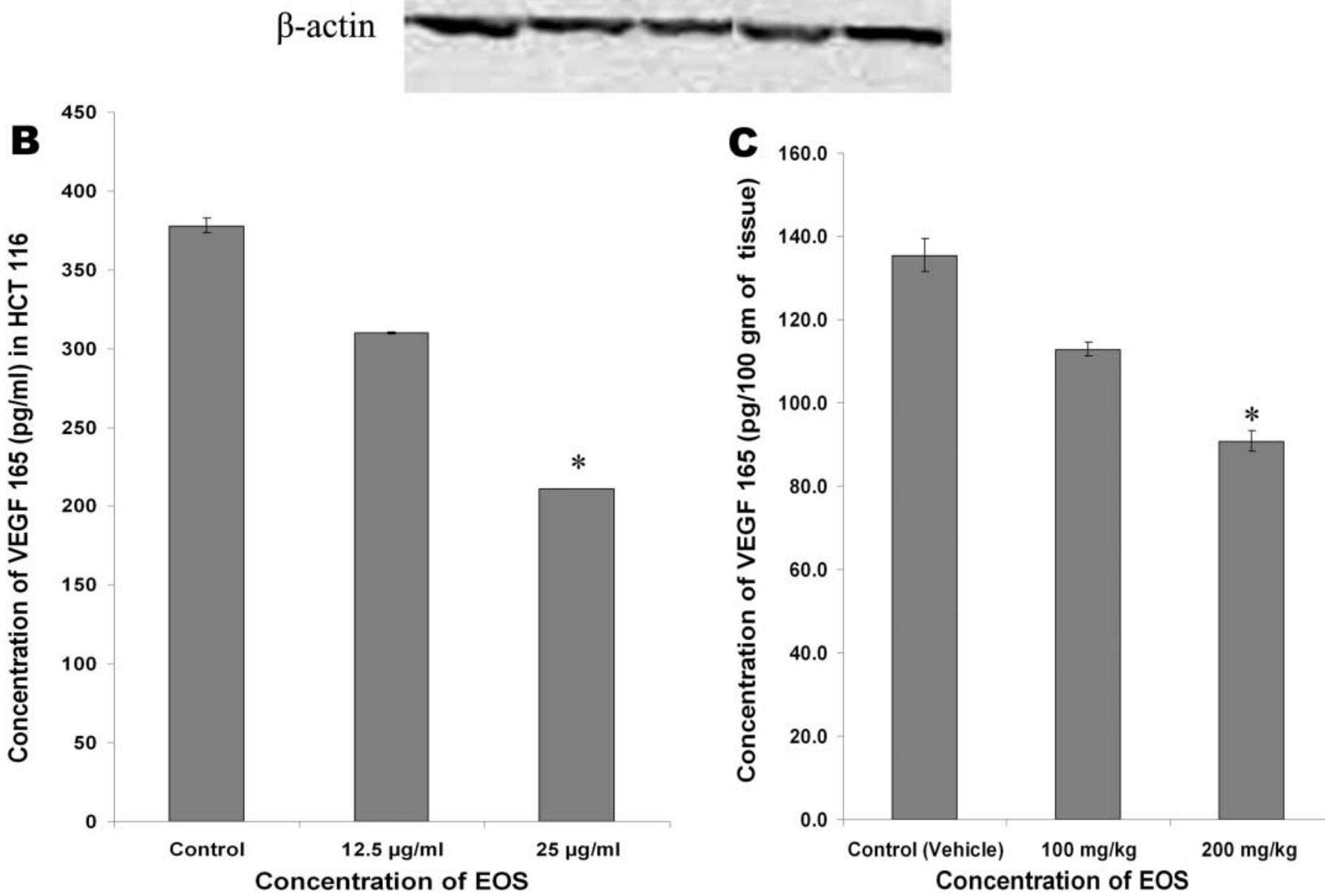

FIG. 5. A: Phosphorylation of VEGFR-2 was assessed by Western blot with antiphospho-VEGFR-2 antibody. The results showed that ethanol extract of O. stamineus leaves (EOS) inhibited phosphorylation of VEGFR-2 in a dose-dependent manner. B: In vitro determination of vascular endothelial growth factor (VEGF) 165 level in HCT 116 cells: The level of VEGF in untreated cells was found to be $378 \pm 5 \mathrm{pg} / \mathrm{ml}$, whereas the treated cells showed $310 \pm 0.82$ and 211 $\pm 0.26 \mathrm{pg} / \mathrm{ml}$ at 12.5 and $25 \mu \mathrm{g} / \mathrm{ml}$ concentration of EOS, respectively $\left(n=6\right.$, values are in mean \pm SEM). ${ }^{*} P<0.05$. C: In vivo determination of VEGF level in colon tumor tissue homogenates: Tumor tissues harvested from placebo control group showed $135.5 \pm 4 \mathrm{pg}$ VEGF/100 g of tissue homogenate, whereas the tumor tissues harvested from the animals treated with 100 and $200 \mathrm{mg} / \mathrm{kg}$ EOS showed $112.9 \pm 2$ and $90.9 \pm 3 \mathrm{pg}$ VEGF/100 g of tissue homogenate, respectively $(n=$ 10 , values are in mean \pm SEM. ${ }^{*}=P<0.05$.

approach has also been confirmed (29). Nevertheless, diterpenes isolated from O. stamineus have been shown to demonstrate antiproliferative activity against highly liver metastatic murine colon 26-L5 carcinoma cells $(30,31)$. Further studies on these diterpenes revealed their efficacies to inhibit the tumour promoter induced inflammation of 12-O-tetradecanoylphorbol-13acetate in mouse model (32). Furthermore, EOS significantly inhibited the key aspects of angiogenesis in endothelial cells, such as migration and tube formation. Rosmarinic acid has been found to be an active caffeoyl ester, predominantly found in O. stamineus, which inhibits several important steps of angiogenesis including proliferation, migration, adhesion, and tube formation of endothelial cells, in addition to retinal neovascularization in a mouse model of retinopathy, which related to blocking of prooxidant-dependent VEGF expression in retina $(27,33)$. Methoxylated flavonoids (eupatorin and sinensetin) are 
important class of bioactive compounds found abundantly in O. stamineus. Eupatorin strongly inhibits in vitro proliferation of cancer cells (34), whereas sinensetin induces apoptosis and CYP1-mediated antiproliferation in human cancers cells $(35,36)$.

In conclusion, the present work provides good supporting evidence that EOS inhibits the growth of colon tumor. The antitumor effect may be due to the collective contribution of phytochemicals particularly, rosmarinic acid, eupatorin, sinensetin, betulinic acid, and 3'-hydroxy-5, 6, 7, 4'-tetramethoxyflavone in EOS. These results convinced that EOS exerts the antiangiogenic effect by blocking VEGF signaling pathway, and eventually the antiangiogenic property could be the principle factor for the potent antitumor property of EOS.

\section{ACKNOWLEDGMENTS}

We gratefully acknowledge the financial support of the Universiti Sains Malaysia, under grant number 1001/PPSK/ 8120243, RU, and Malaysian Ministry of Higher Education, grant number FRGS: 203/PFARMASI/671196. The authors are also thankful to the MAKNA Research Grant No. 304/ PFARMASI/650547/M122. We also acknowledge scientific contributions from Christopher Parish and his group, Cancer and Vascular Biology Centre, John Curtin School of Medical Research, Australian National University, in aiding us to establish the angiogenesis assay system.

\section{REFERENCES}

1. Steeg PS: Metastasis suppressors alter the signal transduction of cancer cells. Nat Rev Cancer 3, 55-63, 2003.

2. Zetter BR: Angiogenesis and tumor metastasis. Ann Rev Med 49, 407-424, 1998.

3. Brekken RA, Overholser JP, Stastny VA, Waltenberger J, Minna JD, et al:: Selective inhibition of vascular endothelial growth factor (VEGF) receptor 2 (KDR/Flk-1) activity by a monoclonal anti-VEGF antibody blocks tumor growth in mice. Cancer Res 60, 5117-5124, 2000.

4. Ferrara N, Hillan KJ, Gerber HP, and Novotny W: Discovery and development of bevacizumab, an anti-VEGF antibody for treating cancer. Nat Rev Drug Discov 3, 391-400, 2004.

5. Mizukami Y and Chung D: Hypoxia, angiogenesis, and colorectal cancer. Curr Colorectal Cancer Rep 3, 71-75, 2007.

6. Perry LM: Medicinal Plants of East and Southeast Asia: Attributed Properties and Uses. Cambridge, MA, MIT Press, 1980.

7. Jaganath IB and $\mathrm{Ng} \mathrm{LT:} \mathrm{Orthosiphon} \mathrm{stamineus.} \mathrm{In:} \mathrm{Herbs,} \mathrm{the} \mathrm{Green}$ Pharmacy of Malaysia. Kaula Lampur, Malaysia: Vinpress, 2000, pp. 7677.

8. Yam MF, Lim V, Salman IM, Ameer OZ, Ang LF, et al.: HPLC and antiinflammatory studies of the flavonoid rich chloroform extract fraction of Orthosiphon Stamineus leaves. Molecules 15, 4452-4466, 2010.

9. Sumaryono W, Proksch P, Wray V, Witte L, and Hartmann T: Qualitative and quantitative analysis of the phenolic constituents from Orthsiphon aristatus. Planta Med 57, 176-180, 1991.

10. Awale S, Tezuka Y, Banskota AH, Adnyana IK, and Kadota S: Nitric oxide inhibitory isopimarane-type diterpenes from Orthosiphon stamineus of Indonesia. J Nat Prod 66, 255-258, 2003.
11. Sahib HB, Aisha AF, Yam MF, Asmawi MZ, Ismail Z, et al.: Antiangiogenic and anti oxidant properties of Orthosiphon stamineus Benth. methanolic leaves extract. Int J Pharmacol 5, 162-167, 2009.

12. Akowuah GA, Zhari I, Norhayati I, Sadikun A, and Khamsah SM: Sinensetin, eupatorin, 3'-hydroxy-5, 6, 7, 4'-tetramethoxyflavone and rosmarinic acid contents and antioxidative effect of Orthosiphon stamineus from Malaysia. Food Chem 87, 559-566, 2004.

13. Lowry, OH, Rosebrough NJ, Farr AI, and Randall JL: Protein measurement with Folin phenol reagent. J Biol Chem 193, 265-275, 1951.

14. Dubois M. Gilles KK, Hamilton JK, Rebers PA, and Smith F: Colorimetric methods for determination of sugars and related substances. Anal Chem 28, 350-356, 1956.

15. Siddiqui MJ, Hafizoh SN, Ismail Z, Sahib HB, Helal MHS, et al.: Analysis of total proteins, polysaccharides and glycosaponins contents of orthosiphon stamineus benth. in spray and freeze dried methanol:water (1:1) extract and its contribution to cytotoxic and antiangiogenic activities. Pharmacog Res 1, 320-326, 2009.

16. Chen JH, Xia, ZH, and Tan RX: High performance liquid chromatographic analysis of bioactive triterpenes in Perilla frutescens. J Pharmaceut Biomed Anal 32, 1175-1179, 2003.

17. Corbett T, Valeriote F, LoRusso P, Polin L, Pancharov C, et al.: In vivo methods for screening and preclinical testing. In: Anticancer Drug Development Guide: Preclinical Screening, Clinical Trials, and Approval, Teicher B and Totowa NJ (eds.). Totowa, NJ: Humana Press, 2000, pp. 75-99.

18. Mosmann T: Rapid colorimetric assay for cellular growth and survival: application to proliferation and cytotoxicity assays. J Immunol Methods $\mathbf{6 5}$, 55-63, 1983.

19. Liang CC, Park AY, and Guan JL: In vitro scratch assay: a convenient and inexpensive method for analysis of cell migration in vitro. Nat Protoc 2, 329-333, 2007.

20. He MF, Huang YH, Wu LW, Ge W, Shaw PC, et al.: Triptolide functions as a potent angiogenesis inhibitor. Int J Cancer 126, 266-278, 2010.

21. Losso JN: Targeting excessive angiogenesis with functional foods and nutraceuticals. Trends Food Sci Technol 14, 455-468, 2003.

22. Maulik N: Redox signaling of angiogenesis. Antioxid Redox Signaling 4, 805-815, 2002.

23. Aslan M and Ozben T: Oxidants in receptor tyrosine kinase signal transduction pathways. Antioxid Redox Signaling 5, 781-788, 2003.

24. Maulik N: Reactive oxygen species drives myocardial angiogenesis? Antioxid Redox Signaling 8, 2161-2168, 2006.

25. Olah NK, Radu L, Mogosan C, Hanganu D, and Gocan S: Phytochemical and pharmacological studies on Orthosiphon stamineus Benth. (Lamiaceae) hydroalcoholic extracts. J Pharmaceut Biomed Anal 33, 117-123, 2003.

26. Mojzis J, Varinska L, Mojzisova G, Kostova I, and Mirossay L: Antiangiogenic effects of flavonoids and chalcones. Pharmacol Res 57, 259-265, 2008.

27. Huang SS, and Zheng RL: Rosmarinic acid inhibits angiogenesis and its mechanism of action in vitro. Cancer Lett 239, 271-280, 2006.

28. Mukherjee R, Jaggi M, Rajendran P, Siddiqui MJA, Srivastava SK, et al.: Betulinic acid and its derivatives as antiangiogenic agents. Bioorg Med Chem Lett 14, 2181-2184, 2004.

29. Wedge SR, Ogilvie DJ, Dukes M, Kendrew J, Chester R, et al.: ZD6474 inhibits vascular endothelial growth factor signaling, angiogenesis, and tumor growth following oral administration. Cancer Res 62, 4645-4655, 2002.

30. Tezuka Y, Stampoulis P, Banskota AH, Awale S, Tran KQ, et al.: Constituents of the Vietnamese medicinal plant Orthosiphon stamineus. Chem Pharmaceut Bull 48, 1711-1719, 2000.

31. Awale S, Tezuka Y, Banskota AH, Kouda K, Tun KM, et al.: Five novel highly oxygenated diterpenes of Orthosiphon stamineus from Myanmar. J Nat Prod 64, 592-596, 2001.

32. Masuda T, Masuda K, Shiragami S, Jitoe A, and Nakatani N: Orthosiphol A and B, novel diterpenoid inhibitors of TPA (12-O-tetradecanoylphorbol-13- 
acetate)-induced inflammation, from Orthosiphon stamineus. Tetrahedron 48, 6787-6792, 1992.

33. Kim JH, Lee BJ, Kim JH, Yu YS, Kim MY, et al.: Rosmarinic acid suppresses retinal neovascularization via cell cycle arrest with increase of p21WAF1 expression. Eur J Pharmacol 615, 150-154, 2009.

34. Androutsopoulos V, Arroo RRJ, Hall JF, Surichan S, and Potter GA: Antiproliferative and cytostatic effects of the natural product eupatorin due to CYP1 mediated metabolism. Breast Cancer Res 10, R39, 2008.
35. Kim H, Moon JY, Mosaddik A, and Cho SK: Induction of apoptosis in human cervical carcinoma HeLa cells by polymethoxylated flavone-rich Citrus grandis Osbeck (Dangyuja) leaf extract. Food Chem Toxicol 48, 2435-2442, 2010.

36. Androutsopoulos VP, Rupareliab K, Arroob RRJ, Tsatsakisa AM, and Spandidosc DA: CYP1-mediated antiproliferative activity of dietary flavonoids in MDA-MB-468 breast cancer cells. Toxicology 264, 162-170, 2009. 